\title{
The Confucian doctrine of the Mean, the optimality principle, and social harmony
}

\author{
JUNGHO SUH*
}

Geography, Environment and Population, School of Social Sciences, The University of Adelaide, Australia

Received: April 15, 2019 • Revised manuscript received: December 6, 2019 • Accepted: December 10, 2019

(C) 2020 The Author(s)

\begin{abstract}
The Confucian doctrine of the Mean teaches that too much is as bad as too little. The Aristotelian doctrine of the Mean coincidently articulates that there can be too much or too little of nearly every human passion and action. In neoclassical economics, it is assumed that people tend to take any action at the optimal (not too much and not too little) level to maximise the net happiness from the action. This article argues that the Confucian doctrine of the Mean concurs with the optimality principle, and therefore that the optimality principle is a representation of human nature and can be understood as universal human wisdom. It follows that people can adopt both the Confucian doctrine of the Mean and the optimality principle as worldly common wisdom beyond the blunt dichotomy of spiritual orientalism and materialistic individualism. Too much emphasis on the technical differentials between the two has undermined the common wisdom embedded in them.
\end{abstract}

\section{KEYWORDS}

the doctrine of the Mean, zhong-yong, utility principle, optimality principle, neoclassical economics

\section{JEL-CODES}

B11, D70, N30

\section{INTRODUCTION}

Both Confucian ethics and utilitarianism deal with human feelings that can be converted into two categories, namely pleasure and pain. Moreover, both Confucianism and utilitarianism centre

*Corresponding author. E-mail: jungho.suh@adelaide.edu.au 
around the concept of optimality. Confucianism sees humans as the subject of feelings, which are stirred by external factors. From the Confucian perspective, all things (e.g. food consumption, blood pressure, body weight, or raining) have their corresponding optimal limits (Cheung et al. 2003). Utilitarianism, which was formed in the 18th century, reintroduced the Greek tradition of psychological hedonism, according to which humans behave in a way to increase pleasure and reduce pain (Heathwood 2014). For example, there must be an ideal level of food consumption by a person at a given point in time or in a given period of time. Additional food consumption above the optimal level can result in an increase in pain or a decrease in pleasure.

Many studies have compared Confucian ethics and utilitarianism and have come to the view that utilitarianism shares little similarity with Confucian ethics. For example, Li (1996) argued that utilitarianism is a worldly philosophy that sees humans as selfish beings, and that Confucianism postulates moral principles which are imperative and should be followed. Cheung et al. (2003) argued that Confucian ethics is in stark contrast with utilitarian rationalism because the Confucian ethics is not oriented to maximising utility. These critiques undermine what might be the common denominator of the two apparently disparate schools of philosophy, given that philosophy is a discipline committed to searching for universal wisdom. Both Confucianism and utilitarianism were formulated in search of such wisdom at different geographical locations and temporal points. Both schools are based on humanism and eudaimonism. Confucius saw every individual human as a sovereign actor in pursuit of happiness. Likewise, classical utilitarians saw humans as pursuing happiness in everyday life, and discoursed on the happiness of ordinary people as opposed to the noble class. Thus, it is worth searching for any commonality between the two schools of philosophy and deriving the implications of the finding to contemporary happiness studies.

The primary objective of this article is to demonstrate that the optimality principle is central to both Confucianism and utilitarianism, mainly with reference to Zhong Yong (The Doctrine of the Mean), an essential text of the Confucian ethics. In fact, Cheng et al. (2003) pointed out that Zhong Yong preaches to choose the 'optimal' course of action. Thus, a question is whether the optimality principle is contradictory to the utility maximisation principle.

This paper first reinforces striking similarities between the Confucian and Aristotelian doctrines of the Mean and then elaborates as to how the Aristotelian doctrine of the Mean has evolved into the utility principle in which the neoclassical economics paradigm is rooted. The paper next expands the discussion on the optimality principle into social and environmental ethics. The implications of the major arguments made in this paper are then highlighted.

\section{THE CONFUCIAN AND ARISTOTELIAN DOCTRINES OF THE MEAN}

The ethical viewpoint of Confucius (551-479 BC) is manifested in the four basic texts of Confucianism: namely, Confucian Analects, the Great Learning, Zhong Yong, the Works of Mencius. Among others, Zhong Yong written by Zisi (483-402 BC), ${ }^{1}$ the only grandson of Confucius, preaches the zhong-yong mentality concerning how to live a human life and govern a country. The opening paragraph of Zhong Yong defines the relationship between heaven, nature and ethics. It reads that 'what heaven has conferred is called the [human] nature; an accordance

\footnotetext{
${ }^{1}$ Although there is no consensus as to whether Zhong Yong was written solely by Zisi or was edited by multiple figures as time passed, it is widely agreed that the book presents the ethical core of Confucian teachings (Sim 2007).
} 
with this nature is called the path of duty; the regulation of this path is called instruction [education]'. The opening chapter of Zhong Yong then articulates that humans are the subject of feelings, as follows:

While there are no stirrings of pleasure, anger, sorrow and joy, the mind may be said to be in the state of equilibrium [zhong]. While those feelings have been stirred, and they act in the due degree, there ensues what may be called the state of harmony. This equilibrium is the great root from which grow all the human actings in the world, and the harmony is the universal path [dao] which they all should pursue (Zhong Yong, Chapter 1, Verse 4).

Zhong-yong is a compound key word throughout the entire book of Zhong Yong. ${ }^{3}$ The word zhong (中) literally means 'middle' or 'centre'. As an ethical term, zhong refers to a situation when one acts in a non-leaning and non-biased way (Cheung et al. 2003). The word yong (庸) refers to 'usefulness', 'application', 'common sense' or 'constancy' (Cheung et al. 2003; Li 2004; Sim 2007). Thus, zhong-yong can be translated into 'the Mean as a useful principle', 'the middle road as common sense' or 'the constant practice of the middle road in everyday life'.

Zhong Yong stipulates that one is in the state of harmony (和) when his or her emotions arise and are moderated at the Mean (中). Treading the path (道) of zhong-yong is not merely taking a position with a mechanically equal distance from opposing options or states, but staying at the optimal position in the course of action (Cheung et al. 2003). Because the middle road is situation-specific, the concept of harmony must be understood in the context of 'timeliness' and 'quality' rather than 'quantity' (Li 2004; 2008). The opening chapter of Zhong Yong continues: 'Let the states of equilibrium and harmony exist in perfection, and a happy order will prevail throughout heaven and earth, and all things will be nourished and flourish' (Zhong Yong, Chapter 1, Verse 5).

Confucius remarked how difficult it is to live up to the zhong-yong principle, saying that there is nobody who does not eat and drink, but there are few who can distinguish taste (Zhong Yong, Chapter 4, Verse 2). In this remark, someone who can distinguish taste is referred to as a person who knows and practises his or her optimal level of food consumption in quantitative terms. Most people consume either too much or too little. Notably, the zhong-yong philosophy often appears in other Confucian works. For example, it is written that 'to go beyond is as wrong as to fall short' (過猶不及 guò yóu bù jí) (Confucian Analects, Book 11, Chapter 15, Verse 3).

Virtue in the aspect of emotional control was one of the main themes scrutinised by many Ancient Greek philosophers including Aristotle (384-322 вс). They had in common that pleasure and pain is the primary motivators of human actions. Aristotle contended that every human passion and action is accompanied by pleasure and pain, and therefore virtue is concerned with pleasures and pains (Nicomachean Ethics, Book II, Chapter 3, 1104b, 10-15). Aristotle pointed out that in everything that is divisible and continuous it is possible for anyone to take too much or too little of it. More importantly, Aristotle maintained that the Mean is not exactly the middle point between excess and defect; Rather, the Mean should be relative to every

\footnotetext{
${ }^{2}$ This paper adopts the English translation by James Legge, The Four Books: Confucian Analects, the Great Learning, the Doctrine of the Mean, and the Works of Mencius. Any words in brackets were added by the author of this article for clarification purposes.

${ }^{3}$ This article hyphenates the words zhong-yong in lower case in order to distinguish it from the title of the book Zhong Yong.
} 
individual; thus, a master of any art avoids excess and defect and seeks the Mean relative to him or her (Nicomachean Ethics, Book II, Chapter 6, 1106a, 25-35).

The Aristotelian doctrine of the Mean concurs with the Confucian doctrine of the Mean to a large extent (Cheung et al. 2003; Sim 2007; Ni 2009). Like Confucius quoted in Zhong Yong, Aristotle stressed that one should take the comprehensive Mean, that is, finding the right target in the given circumstance and hitting it by proper action. Aristotle came to the same view regarding the difficulty of practising the doctrine of the Mean. Aristotle wrote that 'anyone can get angry - that is easy - or spend money or give it away; but to do all this to the right person, to the right extent, at the right time, with the right motive, and in the right manner, is not a thing that everyone can do, and is not easy' (Nicomachean Ethics, Book II, Chapter 9, 1109a, 25).

\section{UTILITARIANISM AND THE OPTIMALITY PRINCIPLE}

Smith (1759[1976]) used the term 'utility' to mean usefulness, pleasure or convenience that is desirable to promote. By the same token, Bentham (1789: ii) elaborated that the term 'utility' means 'property in any object, whereby it tends to produce benefit, advantage, pleasure, good or happiness, or to prevent the happening of mischief, evil or unhappiness to the party whose interest is concerned'. In short, the word 'utility' is representative of something desirable and can be replaced with 'pleasure', 'benefit' or 'happiness' in plain English.

Utilitarianism emerged in the 18th century in parallel with the Greek tradition of psychological hedonism in which humans are seen as a pursuing happiness in everyday life, and pleasure and happiness motivates their behaviours (Zafirovski 2008; Danchev 2016). ${ }^{4}$ Bentham (1789: i) shed light on 'pleasure and pain' as a guide to everyday decisions:
Nature has placed mankind under the governance of two sovereign masters, pain and pleasure. It is for them alone to point out what we ought to do, as well as to determine what we shall do. On the one hand the standard of right and wrong, on the other the chain of causes and effects, are fastened to their throne. They govern us in all we do, in all we say, in all we think.

Bentham (1789) derived the utility principle from human nature. ${ }^{5}$ According to the utility principle, human beings make decisions inherently in a way that leads to the greatest possible happiness by weighing happiness against unhappiness (Persky 1995; Sandel 2009). The utility principle is the philosophical foundation of both classical and neoclassical economics including William Jevons, Léon Walras and Alfred Marshall (Choudhury 1995; Infantino 2003; Zafirovski 2008; Witztum - Young 2013). People, in pursuing happiness, are continuously faced with the limitations of

\footnotetext{
${ }^{4}$ Philosophers in the 18th century endeavoured to establish a fundamental axiom, on the basis of which both politics and law could be reconstructed, appealing to the people as opposed to the monarchs. It is notable that A Fragment of Government (Bentham, 1776[1988]) and The Wealth of Nations (Smith 1776) were published in the same year when the United States of America was declared independent. An Introduction to the Principles of Morals and Legislation (Bentham 1789) was published in the year when the French Revolution broke out. Bentham (1776[1988]: 3) wrote: 'The age we live in is a busy age, in which knowledge is rapidly advancing towards perfection. In the natural world, in particular, everything teems with discovery and with improvement ... Correspondent to discovery and improvement in the natural world is reformation in the moral'.

${ }^{5}$ It is remarkable, whether coincidental or not, the opening paragraph of both Zhong Yong and Bentham (1789) starts with mentioning 'nature' and 'human nature'.
} 
their resources. The limited availability of resources forces people to choose to use scarce resources in such a way that the greatest amount of pleasure can be generated. When an action is found to become more costly and less beneficial, a rational person is expected to do it less. Conversely, when doing the action becomes less costly and more beneficial, the rational person tends to do it more.

A two-dimensional diagram (Fig. 1) illustrates how utilitarianism is embedded in the early neoclassical economic paradigm (e.g. Jevons 1871; Marshall 1890[1961]). Let us assume that Sally and Harry are the only buyers in a local market for fountain water. Each of them determines how many bottles of fountain water they would like to consume along their individual marginal benefit curve. Marginal benefit is what a consumer additionally gains when they consume one additional unit of a product. The additional utility gained from consuming an additional unit of the product in a given period of time tends to diminish as consumption increases. The individual willingness-to-pay curve for fountain water is identical to the individual marginal benefit curve, the reason being that each of the consumers is willing to pay as much as the marginal benefit from any given bottle of water. Along the willingness-to-pay curve, the quantity demanded decreases as the market price of fountain water increases. Sally and Harry demand $\mathrm{q}_{*}$ bottles of water in total when the market price per bottle is $p_{*}$.

Let us assume that Robert and Jenny are the only local producers of fountain water. Each of them determines how much fountain water they would like to produce along their individual marginal cost curve. Marginal cost is the additional cost required to produce one additional unit of a product. The additional cost of producing an additional unit of the product in a given period of time tends to increase as production increases due to resource scarcity. The individual supply curve for fountain water is identical to the individual marginal cost curve. The producers want to be paid at least as much as the marginal cost of any given bottle of water. Along the marginal cost curve, the quantity supplied increases as the market price of fountain water increases. Robert and Jenny supply $q_{*}$ bottles of water in total when the market price per bottle is $p_{*}$.

Optimality is one of the key concepts in neoclassical economics. It is derived from the law of diminishing marginal benefits, and the law of increasing opportunity costs of taking an additional increment of an action. Rational decision-makers are supposed to choose the optimal level of the action in a given period of time because the greatest net benefits from the action can be achieved if and only if the optimal level of the action is undertaken. Graphically with the example of bottled water, the marginal cost and marginal benefit curves determine the socially optimal water consumption or production level. The total net benefit is maximised when the water is consumed or produced at $q_{*}$ in Fig. 1. The shaded area of a triangle in Fig. 1 is the sum of net benefits measured by the vertical distance between marginal benefits and marginal costs at any given quantity in a range of 0 to $q_{*}$. The sum of the net benefits can be maximised only when fountain water is consumed and produced at $q_{*}$ where the marginal benefit is equal to the marginal cost. If the marginal benefit of water consumption exceeds the marginal cost of water production, water production should be expanded. If the marginal cost of water production exceeds the marginal benefit of water consumption, water production should be contracted. In sum, the greatest benefit of the greatest number, which involves the two consumers (Sally and Henry) and the two producers (Robert and Jenny), can be achieved only when the optimal level of bottled water is produced and consumed. Anything more or less than $q_{*}$ on this occasion will result in reducing the total net benefits to all the parties in the market.

From the neoclassical economics perspective, it can be generalised that the optimal level of an action is determined where the marginal benefit and the marginal cost of the action are equal. 


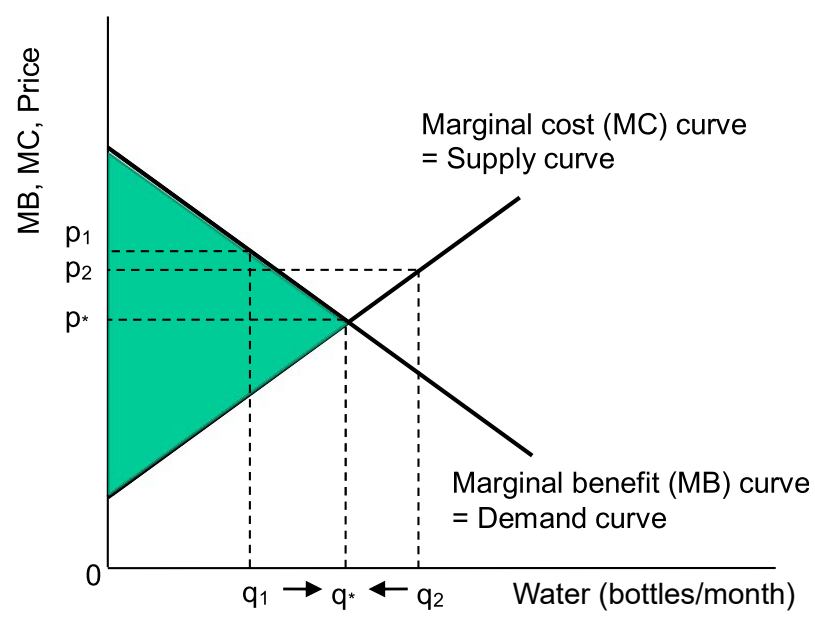

Source: Author

Figure 1. The utility principle and the optimality principle

Moreover, the utility maximisation principle is equivalent to the optimality principle because the total net utility of any passion and action can be maximised only when it is moderated or regulated at the optimal level. Overall, the concept of 'utility' in utilitarianism has been elementary to the evolution of neoclassical economics (Haslett 1990). The word 'utility' can arguably translate in 'benefits', which are assumed to be quantifiable in dollar terms.

Bentham (1789) argued that the utility principle cannot be refuted although there may be disagreements with regard to what pleasure means, how it can be measured, whose happiness is taken into consideration, and so on. ${ }^{6}$ Against Bentham's perspective, however, utilitarianism is often falsely accused of being materialism that focuses only on worldly happiness. Mill (1861 [1961]) pointed out that the term 'happiness' in the utility principle does not refer to Epicurean pleasure, but embraces intellectual, aesthetic and moral pleasures as well. Utilitarianism brought attention to 'happiness' but never argued that happiness is the only motivation of every act and is the only ethical instrument with which an act is judged right or wrong. This false criticism has been socially constructed by a number of philosophical thinkers and researchers.

\section{THE CONFUCIAN DOCTRINE OF THE MEAN, AND SOCIAL HARMONY}

Zhong Yong emphasises that individual self-interest should be in accordance with society. This indicates that self-interest does not necessarily lead to social efficiency. It is notable that Zhong Yong postulates the so-called silver rule of an act when the act involves other people. The silver

\footnotetext{
${ }^{6}$ The utility theory has evolved for more than two centuries into various forms including rule utilitarianism, act utilitarianism, liberal utilitarianism and egalitarian utilitarianism.
} 
rule takes a negative form of the golden rule: namely, 'don't do unto others what you would not have them do unto you'.

When one cultivates to the utmost the principles of his nature, and exercises them on the principle of reciprocity, he is not far from the path $[d a o]$. What you do not like when done to yourself, do not do to others (Zhong Yong, Chapter 13, Verse 3).

The silver rule reflects the notion that people do not want to be treated the way they would not treat others because people want to avoid pains that can be caused by other people (Huang 2005; Bouckaert - Zsolnai 2012). If everyone follows the silver rule, it can be expected that less pain would be generated from social interactions among individuals. This way, possible social conflicts can be avoided and society can remain in harmony.

Zhong Yong (Chapter 20, Verse 8) quotes Confucius stating that all social relationships can be reduced to five types: between sovereign and minister, between husband and wife, between father and son, between siblings, and between friends. Among others, the 'husband-and-wife' relationship represents all forms of social relationship. ${ }^{7}$ A husband and a wife are originally from different families, and form a new family. Thus, a husband or a wife is advised to exercise self-discipline in practising zhong-yong, taking into account the happiness of the other half. Zhong Yong iterates that a sense of public values can be drawn from a sense of family ( $\mathrm{Tu} 2002$ ). For example, a ruler should be in a habit of taking two extremes, determine the Mean without inclining to either side, and employ it in their government of the people (Zhong Yong, Chapter 6).

The zhong-yong mode is extended to the relationship between humans and the rest of the world. For example, people are supposed to fish with a line but not with a net. Likewise, they should not aim at a roosting bird while fowling (Confucian Analects, Book 7, Chapter 26). The zhong-yong philosophy teaches that humans should not over-exploit or under-utilise natural resources. Instead, it allows humans to harvest renewable natural resources such as fish at a rate in which their stock can be maintained. In this sense, Confucian environmental ethics can be labelled anthropocosmism rather than anthropocentrism (Wong 2015).

Zhong Yong acknowledges how important yet difficult it is to take a timely action or reaction every moment and situation, no matter whether it concerns about interpersonal or humannature relationship. The Confucian ideal of the zhong-yong society presupposes that the current society is not perfect and that humans are not perfectly rational decision-makers. There is no perfect agent who is in the state of equilibrium at all times. Neither is there a perfect society where all individuals are in harmony with everything else, which keeps changing over time. Nevertheless, Confucius throughout Zhong Yong preaches that humans must try to keep practising zhong-yong to make the world move towards perfection.

\section{UTILITARIANISM AND SOCIAL HARMONY}

Utilitarianism holds psychological hedonism that every human is concerned about their own pleasures and pains, and puts forward ethical hedonism that it should be the effects on the

\footnotetext{
${ }^{7}$ Aristotle (Politics, Book I) discussed how to govern within individual households (oikoi) through appropriate norms (nomoi). Aristotle's focus was on economic ethics at the household level (Dierksmeier - Pirson 2009), rather than the social relationship between a husband and a wife. Nevertheless, it can be said that Aristotle deemed households as a basic unit of society (Vivenza 2007).
} 
happiness of all the affected parties that determines what people ought to do (Sidgwick 1962; Sprigge 1999). Bentham (1789: ii) postulated that the utility principle 'approves or disapproves of every action whatsoever, according to the tendency which it appears to have to augment or diminish the happiness of the party whose interest is in question'.

Utilitarianism is often mistakenly understood as meaning that utilitarian action takes on a monological horizon in its effort to maximise one's own utility. In fact, the utility principle is a guiding principle for legislators and policy-makers as well as private individuals.Bentham (1776 [1988]: 3) asserted that it is the greatest happiness of the greatest number that is the measure of right or wrong. ${ }^{8}$ Bentham (1789: ii) clarified that the utility principle should be interpreted as meaning the greatest happiness of 'the party whose interest is in question': if the affected party is a community, the utility principle then refers to the greatest happiness of the community; if only a particular individual is affected, then the happiness of that individual. An action taken by a particular person or a policy implemented by a government may be said to be consistent with the utility principle if the happiness generated by that action or policy is greater than the pain caused.

The utility principle consists of two aims: 1) to maximise the amount of happiness; and 2) to maximise the number of people able to enjoy it. Woods (1925) came to the point that the 'greatest happiness of the greatest number' formula was ambiguous because the two aims were unlikely to coexist consistently in all cases. The words 'greatest number' could imply 'the majority of the population'. If this is the case, the utility principle can be criticised as disregarding the happiness of a minority. The same phrase 'greatest number' could also mean 'all the people' involved with an emphasis on equity amongst them.

Utilitarianism has evolved into two directions in terms of distributive justice, depending on how the greatest number principle is treated. ${ }^{9}$ Individualistic liberal utilitarians may advocate that the happiness of a society can be measured by the sum of the happiness of individuals and this can be at its highest when all individuals pursue their own interests. Egalitarian utilitarians may come to the view that the total amount of happiness can be at its highest when wealth and income are equally distributed to all individuals.

Utilitarianism takes Adam Smith's optimistic view of social harmony. Smith (1759[1976]) was optimistic about mutual sympathy with which people would consider overall benefits to society as well as private individuals. Smith (1776[1950]: 456) even argued that 'by pursuing his own interest he frequently promotes that of the society more effectively than when he really intends to promote it'. This remark is often quoted to explain the institutional strength of free market economy. Consumers and producers pursue their own self-interest and interact in markets. The market mechanism invisibly leads the market to equate marginal benefits (or quantity demanded) with marginal costs (or quantity supplied). Market transactions in a free

\footnotetext{
${ }^{8}$ The origin of the phrase 'the greatest happiness of the greatest number' can be traced to Francis Hutcheson's (16941746) book Inquiry into the Original of our Ideas of Beauty and Virtue first published in 1725. For the historical review of the phrase, the readers are referred to Shackleton (1972) and Burns (2005).

${ }^{9}$ Utilitarianism as an ethical theory was introduced to China by Yen Fu in the late 19th century (Li 1996). Yen Fu was instrumental in introducing utilitarianism into Chinese thought was a Confucian philosopher. It is notable that 'utility' is often translated into 功利[gōnglì] in Chinese, which has a connotation of 'individualistic self-interest', but sometimes translated into 公利[gōngli] as well, which accentuates 'the benefits for the general public'. The inconsistent and confusing Chinese translation (功利主義 or 公利主義) of 'utilitarianism' reflects the problem of combining psychological hedonism (the maximisation of individual happiness) and ethical hedonism (the maximisation of social happiness).
} 
market economy generate the highest possible total net social benefit (social surplus), and therefore can lead to the efficient use of resources.

Mill (1861[1961]) argued that humans share the feeling that one's personal interests should be in harmony with other people's interests, although the feeling in most individuals is inferior in strength to their selfish interests. ${ }^{10}$ Utilitarianism adopts the so-called golden rule as a guide as to what one can do with others. Mill (1861[1961]: 204) wrote:

In the golden rule of Jesus of Nazareth we read the complete spirit of the ethics of utility. To do as you would be done by others, to love your neighbours as yourself, constitute the ideal perfection of utilitarian morality.

The golden rule is based on the notion that people want to be treated the way they would treat others because people want to increase or enhance pleasure by interacting with others. If everyone follows the golden rule, a greater pleasure to the whole society would be generated from social interactions among individuals. However, this may not be the case at all times because it is not guaranteed that what is believed to be good to some is good to others. By contrary, what is believed to be good to some may turn out to be harmful to others. In this case, practising the golden rule may create social conflicts rather than harmony.

The optimality principle in neoclassical economics points to maximising utility in an interpersonal relationship of the market. The market supply curve presented in Fig. 1 is the horizontal sum of the individual supply curves. Likewise, the market demand curve is the horizontal sum of the individual demand curves. The graph illustrates that the maximisation of an individual utility, which is taken as an abstract assumption in neoclassical economics, leads to the maximisation of the aggregate utility.

The mechanism of utility maximisation described in Fig. 1 is based on a few assumptions. First, it is assumed that every decision-maker is perfectly informed of their own marginal benefit or marginal cost curve. Second, the position of the marginal benefit and marginal cost curves are fixed over time with an assumption that all other variables remain constant. Third, every decision-maker is assumed to be able to consume or produce at the notional optimal level regardless of their financial capacity or resource endowment. These assumptions are all unrealistic. People are not perfectly informed to be able to locate the optimal of every action in everyday life, and their psychological preferences and external factors keep changing over time (Thaler 2015). ${ }^{11}$ For these reasons, their optimal outcome of choices is not always achievable at the individual level, let alone at the social level. ${ }^{12}$

\footnotetext{
${ }^{10}$ Edgeworth (1881) brought attention to the conflict between egoism and altruism in the determination of individual behaviour. As to whether human behaviour is influenced by the former or the latter, Sen (1987) and Tu (1999) argued that the latter is more influential whereas Stigler (1981) argued that the former is more influential.

${ }^{11}$ Aristotle (Politics, Book II, Chapter 3, 1261b, 30) stated that everyone thinks chiefly of their own interest, hardly at all of the common interest, and therefore what is in the best interest of the greatest number has the least care bestowed upon it. This phenomenon has translated into prisoners' dilemmas in the social science literature (Luce - Raiffa 1957; Ostrom 1990).

${ }^{12}$ One of the problems associated with utilitarianism is its inability to measure utility objectively (Schubert 2012). As a matter of fact, humans can and often do make errors in making choices partly because it is too difficult for them to calculate all the benefits and costs precisely or because their information is incomplete. Nevertheless, this does not change the fundamental utilitarian proposition fact that humans seek greater happiness wherever they are (Stigler 1981).
} 
As for environmental ethics, neoclassical economics takes an anthropocentric view based on behavioural assumptions that reflect the utilitarian understanding of human nature. In the utilitarian perspective, zero pollution is normally not desirable and there can be too much pollution reduction as well as too little pollution reduction. This is because marginal abatement costs are increasing whereas marginal damage of pollution is diminishing. From the neoclassical economics standpoint, the natural environment is exploited or conserved to the optimal level. However, free market economy often fails to achieve the optimal economic outcome because of the abovementioned reasons. Therefore, neoclassical economists advocate that government intervention is required with appropriate policy measures to fix market failure.

\section{DISCUSSION}

Humans are called Homo sapiens (thinking beings). Human beings think economically, socially, politically and ethically. Thus, humans are also called economic, ethical, social and political beings. Only because humans are defined as economic beings, that does not mean they are not social, political, or ethical beings. Economics is often defined as 'the science of human choice' (Mundell 1968; Buchanan 1969; Samuelson - Nordhaus 1980; Coase 1988). With the definition of economics broadened into the study of choice from the study of utility maximisation, economics and ethics should not be separate disciplines (Sen 1987). Indeed, economic decisions explicitly or implicitly involve ethical judgements, which in turn involve economic decisions.

Neoclassical economics inherited utilitarianism, which sees humans as both Homo economicus (economic beings) and Homo ethicus (ethical beings). Homo economicus in this paper means that humans are the subject of pleasure and pain, and they make choices of action in pursuing the greatest net pleasure. In the neoclassical economics paradigm, people in everyday life are assumed to weigh the marginal benefit against the marginal cost of an increase in an action (Jevons 1871; Marshall 1890[1961]). As demonstrated with Fig. 1, any decision made in this way points to the optimal $\left(q_{*}\right)$ level of an action because the greatest net benefits from the action can be achieved if and only if the optimal level of the action is taken. In the neoclassical accounts, the optimal level of the action is the economically and ethically most ideal choice.

The optimality principle in the neoclassical economics context is akin to the Confucian doctrine of the Mean. Zhong Yong discuses pleasure as well as other forms of human emotions whereas neoclassical economics discuses utility by using money as a surrogate. The optimality principle depicted in Fig. 1 points to a situation where water consumption or production is not more than $q_{*}$ and not less than $q_{*}$. As in the Confucian doctrine of the Mean, there can be too much or too little of any human passion and action; too much or too little running, too much or too little water consumption.

The Mean in the Confucius context connotes a qualitative virtue. For this reason, one may argue that the Confucian doctrine of the Mean does not resemble the optimality principle, which fundamentally aims to simplify the complex phenomena for quantitatively maximising benefits. However, the quality of pleasure in Confucian thought is at its highest when it is controlled at the point of zhong-yong, that is, not too much and not too little. The zhong-yong principle conveys the meaning of timeliness or optimality in an intuitive manner whereas neoclassical economics delivers that in an analytical manner based on marginalism. 
This article reinforces an overarching proposition that the precepts of zhong-yong and optimality are converging to each other. The optimality principle is central to not only Confucianism and utilitarianism, but also many other disciplines including psychology, politics and sociology. An analogy is that photosynthesis is relevant to a wide range of disciplines including chemistry, biology, physics, philosophy, religion and education (Matthews 2009). Table 1 summarises the comparative similarities and differences between the Confucian doctrine of the Mean and the optimality principle.

The silver rule and the golden rule have in common that someone else's pains or benefits are to be factored into someone's happiness equation. Allinson (1992) pointed out that the Confucian negative formulation of the golden rule is more humane than that of the positive version. The silver rule does not require presuming that what is good for some would definitely be good for some others. It is arguably easier for one to know and avoid what might be harmful to others than to know and do what is beneficial to others (Wattles 1987). If one does not know whether their act is benevolent by nature, it would be better to follow the silver rule in order to avoid possibly harming others (Allinson 1992).

The narrow interpretation of utilitarianism makes the distance between Confucianism and utilitarianism look farther apart than they are. Confucianism presents the doctrine of the Mean as intuitive wisdom. By contrast, neoclassical economics has evolved with rigorous mathematical

Table 1. Conceptual comparison across the Confucian Mean and the neoclassical optimality principle

\begin{tabular}{|c|c|c|}
\hline Aspect & Confucian Mean & Optimality principle \\
\hline Pursuit of happiness & $\begin{array}{l}\text { Living up to Mother Nature; } \\
\text { teleological eudaimonism }\end{array}$ & $\begin{array}{l}\text { Psychological and ethical } \\
\text { hedonism }\end{array}$ \\
\hline $\begin{array}{l}\text { Ontological understanding of } \\
\text { humans }\end{array}$ & $\begin{array}{l}\text { Primarily ethical beings yet } \\
\text { synonymous with economic } \\
\text { beings }\end{array}$ & $\begin{array}{l}\text { Primarily economic beings yet } \\
\text { synonymous with ethical beings }\end{array}$ \\
\hline Epistemological approach & Intuitive and descriptive & Mechanical and mathematical \\
\hline $\begin{array}{l}\text { Quantity versus quality of } \\
\text { happiness }\end{array}$ & $\begin{array}{l}\text { The quality of pleasure, which is } \\
\text { dependent on the quantity of the } \\
\text { source of pleasure (e.g. food) }\end{array}$ & $\begin{array}{l}\text { The quantity of pleasure, which is } \\
\text { dependent on the quantity of the } \\
\text { source of pleasure (e.g. food) }\end{array}$ \\
\hline Evaluation of act & Timeliness and relative Mean & Utility maximisation \\
\hline Personal equilibrium & $\begin{array}{l}\text { Difficult to be at a state of zhong- } \\
\text { yong at every moment with every } \\
\text { action }\end{array}$ & $\begin{array}{l}\text { Assumed equilibrium at a personal } \\
\text { level }\end{array}$ \\
\hline Social harmony & $\begin{array}{l}\text { Individual virtue and smart } \\
\text { governance }\end{array}$ & $\begin{array}{l}\text { Assumed social equilibrium that } \\
\text { leads to the greatest happiness } \\
\text { of the greatest number }\end{array}$ \\
\hline Social norm of interpersonal act & The silver rule & The golden rule \\
\hline Environmental ethics & Anthropocosmism & Anthropocentrism \\
\hline
\end{tabular}

Source: author. 
analysis techniques such as marginal analysis and general equilibrium (Thaler 2000; Sandelin et al. 2014). With its mathematical approach, neoclassical economics divorced economic beings from ethical beings (Sen 1987) since the early 20th century. The similarity of the ultimate message of Zhong Yong and utilitarianism has been overshadowed by the development of neoclassical economics into the mathematical domain. Too much emphasis on the technical differentials between the two has undermined common wisdom embedded in them. Confucianism and utilitarianism look divergent on this theme.

\section{CONCLUSIONS}

This article proves that the Confucian doctrine of the Mean and the optimality principle are conceptually complementary to each other in terms of their understanding of human nature, regardless of the economic development stages at the time of their emergence: one in a feudalistic society and the other in a capitalistic society. Confucianism is not an explanation of feudalism or a product of feudalism. Likewise, utilitarianism is not just a product of capitalism. Both precepts of zhong-yong and optimality are the products of an endeavour to understand the economic and ethical nature of human beings and to bridge the arenas of personal morality and social harmony.

Both Confucianism and utilitarianism derive 'what humans are' from Mother Nature, and derive 'what they ought to do' from 'what they are'. ${ }^{13}$ In the Confucian perspective, what is wrong or right is determined by the nature of humans. This is similar in the utilitarian perspective. Confucianism posits that a whole society can be in zhong-yong equilibrium if every individual member of the society is psychologically and morally in zhong-yong equilibrium. This is the case with utilitarianism. Utilitarianism is often narrowly understood as upholding an egoistic and materialistic worldly philosophy within the individualistic constituency. In fact, utilitarianism offers a much broader context than individualism (Riley 1988), given that utilitarianism concerns the interests of all the affected parties, and whether these are taken into account.

The main arguments of this paper have progressed in the following order. First, the Confucian doctrine of the Mean denotes a timely and optimal choice of action and passion. Second, utilitarianism postulates that people choose a level of action and passion at the point where the total utility from the action and passion is maximised. Third, total utility is maximised when the optimal level of action is chosen. Finally, the Confucian doctrine of the Mean concurs with the optimality principle. Therefore, the Confucian doctrine of the Mean is not contradictory to the utility maximisation principle in logical terms. These arguments imply that people can adopt both the Confucian doctrine of the Mean and the optimality principle as a worldly philosophy without falling in a self-contradictory situation. In other words, business sectors do not have to be forced to choose either the Confucian doctrine of the Mean or the utility maximisation principle because these two are not mutually exclusive and can rather be considered to be complementary to each other.

\footnotetext{
${ }^{13}$ This is the reason why there is no dividing boundary between religion and ethics in Confucianism. Zhong Yong denies a dualism of matter versus spirit and humans versus non-humans (Tu 2001).
} 
The significance of the arguments made in this article may be limited in that it opted to choose quotes mainly from classical utilitarians including Jeremy Bentham and John Stuart Mill. The assertion that utilitarianism is an adequate description of human behaviour has received a great deal of criticism. First of all, the ethical theory of utilitarianism that people choose an action that maximises the total net happiness is criticised as consequentialism. If the consequence of an act is an evil to a minority, will pursuing it be an evil to the whole society? Second, the meaning of the greatest number principle is notoriously difficult to decipher due to its ambiguity. Third, a society may adopt the utility principle because it is equitably beneficial to its members, but it is questionable whether the right and wrong ends of acts can be determined by the utility principle. If the end of an act is an evil, pursuing it can be an evil too regardless of the utility that may be generated. Despite these problems, however, it should not be undermined that zhong-yong as an ethical maxim is in parallel with the utility principle and the optimality principle.

\section{REFERENCES}

Allinson, R. E. (1992): The Golden rule as the Core Value in Confucianism and Christianity: Ethical Similarities and Differences. Asian Philosophy 2(2): 173-185.

Aristotle (1952a): Nicomachean Ethics, translated by Ross, W. A. In: Hutchins, R. M. (ed.): The Works of Aristotle, vol. II. Chicago: Encyclopaedia Britannica, pp. 333-436.

Aristotle (1952b): Politics, translated by Jowett, B. In: Hutchins, R. M. (ed.): The Works of Aristotle, vol. II. Chicago: Encyclopaedia Britannica, pp. 445-548.

Bentham, J. (1776[1988]): A Fragment on Government. Cambridge: Cambridge University Press.

Bentham, J. (1789): An Introduction to the Principles of Morals and Legislation. London: Payne.

Bouckaert, L. - Zsolnai, L. (2012): Spirituality and Business: An Interdisciplinary Overview. Society and Economy 34(3): 489-514.

Buchanan, J. M. (1969): Is Economics a Science of Choice?. In: Streissler, E. (ed.), Road Freedom: Essays in Honour of Friedrich A. von Hayek. London: Routledge, pp. 47-64.

Burns, J. H. (2005): Happiness and Utility: Jeremy Bentham's Equation. Utilitas 17(1): 46-61.

Cheung, T. - Chan, H. - Chan, K. - King, Y. (2003): On Zhongyong Rationality: The Confucian Doctrine of the Mean as a Missing Link between Instrumental Rationality and Communicative Rationality. Asian Journal of Social Science 31(1): 107-127.

Choudhury, M. A. (1995): Ethics and Economics: A View from Ecological Economics. International Journal of Social Economics 22(2): 40-60.

Coase, R. H. (1988): The Firm, the Market and the Law. Chicago: University of Chicago Press.

Danchev, S. (2016): Was Bentham a Primitive Rational Choice Theory Predecessor?. European Journal of the History of Economic Thought 23(2): 297-322.

Dierksmeier, C. - Pirson, M. (2009): Oikonomia versus Chrematistike: Learning from Aristotle about the Future Orientation of Business Management. Journal of Business Ethics 88: 417-430.

Edgeworth, F. (1881): Mathematical Psychics: An Essay on the Application of Mathematics to the Moral Sciences. London: Kegan Paul.

Haslett, D. W. (1990): What is Utility? Economics and Philosophy 6: 65-94. 
Heathwood, C. (2014): Subjective Theories of Well-being. In: Eggleston, B. - Miller, D. E. (eds): The Cambridge Companion to Utilitarianism. New York: Cambridge University Press, pp. 199-219.

Huang, Y. (2005): A Copper Rule versus the Golden Rule: A Daoist-Confucian Proposal for Global Ethics. Philosophy East \& West 55(3): 394-425.

Infantino, L. (2003): Ignorance and Liberty. London: Routledge.

Jevons, W. S. (1871): The Theory of Political Economy. London: Macmillan.

Li, C. (2004): Zhongyong 中庸 as Grand Harmony: An Alternative Reading to Ames and Hall's Focusing the Familiar. Dao: A Journal of Comparative Philosophy 3(2), 173-188.

Li, C. (2008): The Ideal of Harmony in Ancient Chinese and Greek Philosophy. Dao 7: 81-98.

Li, Q. (1996): The Principle of Utility and the Principle of Righteousness: Yen Fu and Utilitarianism in Modern China. Utilitas 8(1): 109-126.

Luce, R. D. - Raiffa, H. (1957): Games and Decisions. New York: Wiley.

Marshall, A. (1890[1961]): Principles of Economics. London: Macmillan.

Matthews, M. R. (2009): Science and Worldviews in the Classroom: Joseph Priestley and Photosynthesis. In: Matthews, M. R. (ed.): Science, Worldviews and Education. Dordrecht: Springer, pp. 271-302.

Mill, J. (1861[1961]): Utilitarianism. In: Lerner, M. (ed.): Essential Works of John Stuart Mill. London: Bantam Books, pp. 189-252.

Mundell, R. A. (1968): Man and Economics. New York: McGraw Hill.

Ni, P. (2009): How Far is Confucius as Aristotelian? Comments on May Sim's Remastering Morals with Aristotle and Confucius. Dao 8: 311-319.

Ostrom, E. (1990): Governing the Commons: The Evolution of Institutions for Collective Action. Cambridge: Cambridge University Press.

Persky, J. (1995): The Ethology of Homo Economicus. Journal of Economic Perspectives 9(2), 221-231.

Riley, J. (1988): Liberal Utilitarianism: Social Choice Theory and J.S. Mill's Philosophy. Cambridge: Cambridge University Press.

Samuelson, P. A. - Nordhaus, W. D. (1980): Economics. New York: McGraw Hill.

Sandel, M. J. (2009): Justice: What's the Right Thing to Do?. New York: Farrar, Straus and Giroux.

Sandelin, B. - Trautwein, H. - Wundrak, R. (2014): A Short History of Economic Thought. New York: Routledge.

Schubert, C. (2012): Pursuing Happiness. Kyklos 65(2): 245-261.

Sen, A. (1987): On Ethics and Economics. New Delhi: Oxford University Press.

Shackleton, R. (1972): The Greatest Happiness of the Greatest Number: The History of Bentham's Phrase.

Studies on Voltaire and the Eighteenth Century 90:1461-1482.

Sidgwick, H. (1962): Methods of Ethics, seventh ed. London: Macmillan.

Sim, M. (2007): Remastering Morals with Aristotle and Confucius. Cambridge: Cambridge University Press.

Smith, A. (1759[1976]). In: Raphael, D. D. - Macfie, A. C. (eds): The Theory of Moral Sentiment. Oxford: Clarendon Press.

Smith, A. (1776[1950]). In: Cannan, E. (ed.): An Inquiry into the Nature and Causes of the Wealth of Nations. London: Methuen.

Sprigge, T. L. S. (1999): The Relation between Jeremy Bentham's Psychological, and His Ethical, Hedonism. Utilatas 11(3): 296-319.

Stigler, G. J. (1981): Economics or Ethics. In: McMurrin S. M. (ed.): The Tanner Lectures on Human Values, vol. II. Salt Lake City: University of Utah Press, pp. 143-191.

Thaler, R. H. (2000): From Homo Economicus to Homo Sapiens. Journal of Economic Perspectives 14(1), 133-141. 
Thaler, R. H. (2015): Misbehaving: The Making of Behavioural Economics. New York: Norton.

Tu, W. (1999): A Confucian Perspective on the Core Values of the Global Community. The Review of Korean Studies 2: 25-70.

Tu, W. (2001): The Ecological Turn in New Confucian Humanism: Implications for China and the World. Daedalus 130(4): 243-264.

Tu, W. (2002): Confucianism and Liberalism. Dao: A Journal of Comparative Philosophy 2(1): 1-20.

Vivenza, G. (2007): Happiness, Wealth and Utility in Ancient Thought. In: Bruni, L. - Porta, P. L. (eds): Handbook on the Economics of Happiness. Cheltenham: Edward Elgar, pp. 3-23.

Wattles, J. (1987): Levels of Meaning in the Golden Rule. The Journal of Religious Ethics 15(1): 106-129.

Witztum, A. - Young, J. T. (2013): Utilitarianism and the Role of Utility in Adam Smith. The European Journal of the History of Economic Thought 20(4): 572-602.

Wong, P. H. (2015): Confucian Environmental Ethics, Climate Engineering, and the "Playing God" Argument. Zygon 50(1): 28-41.

Woods, A. (1925): The Greatest Happiness Regardless of Number. International Journal of Ethics 35(4): 413-425.

Zafirovski, M. (2008): Classical and Neoclassical Conceptions of Rationality-Findings of an Exploratory Survey. The Journal of Socio-Economics 37: 789-820.

Open Access. This is an open-access article distributed under the terms of the Creative Commons Attribution-NonCommercial 4.0 International License (https://creativecommons.org/licenses/by-nc/4.0/), which permits unrestricted use, distribution, and reproduction in any medium for non-commercial purposes, provided the original author and source are credited, a link to the CC License is provided, and changes - if any - are indicated. 